\title{
OS FATORES DE MANUTENÇÃO E DE SUBSTITUIÇÃO DE LÍNGUA POLONESA NO CONTEXTO RURAL NO PARANÁ (1876 - 2018)
}

\author{
Factors of Polish Language Maintenance and Shift in a Rural Context in \\ Paraná (1876-2018)
}

\author{
Alicja GOCZYŁA FERREIRA \\ Universidade Federal do Paraná \\ alicja.ferreira@ufpr.br \\ https://orcid.org/0000-0002-8986-0685
}

\begin{abstract}
RESUMO: O objetivo do presente trabalho é analisar os fatores de manutenção e/ou de substituição da língua polonesa entre os polonodescendentes, usando como exemplo a situação linguística observada em uma das comunidades rurais próximas a Curitiba. Durante uma pesquisa sociolinguística realizada na Colônia Dom Pedro II observou-se indícios de um processo avançado de substituição da língua polonesa. Durante a pesquisa averiguou-se que um dos principais fatores responsáveis inicialmente pela manutenção e, posteriormente, pela substituição da língua polonesa na comunidade foram as condições socioeconômicas presentes na Colônia. Uma análise das biografias linguísticas dos informantes aponta para uma mudança civilizatória considerável, a qual teve seu início no começo dos anos 1970 e levou ao progressivo abandono da língua dos ancestrais entre os moradores da Colônia. No presente trabalho serão expostos também opiniões dos informantes acerca da situação linguística da comunidade e, particularmente, dos fatores de manutenção/substituição linguística por eles observados. PALAVRAS-CHAVE: Língua polonesa no Brasil; Línguas de imigração; Manutenção e Substituição Linguística.
\end{abstract}

\begin{abstract}
The aim of this article is the analysis of the factors of Polish language maintenance and/or shift among Polish descendants in Brazil, using as an example a linguistic situation of a rural community near Curitiba. Some indications of a Polish language shift process have been observed as a result of a sociolinguistic research held in Colônia Dom Pedro II. The findings of the research show that one of the main factors responsible, at first, for the maintenance and, afterwards, for the language shift in the community were the socio-economic conditions present in the community. The analysis of informants' linguistic biographies indicates a considerable civilizational change, which started in early $70 \mathrm{~s}$ of the $20^{\text {th }}$ century and led to a gradual shift from Polish language among the community's inhabitants. The paper also
\end{abstract}


presents the informants' opinions regarding the linguistic situation in the community, especially the maintenance and shift factors they observed. KEY WORDS: Polish language in Brazil; Immigration languages; Language Maintenance and Shift.

STRESZCZENIE: Celem niniejszej pracy jest analiza czynników zachowania i przesunięcia językowego w odniesieniu do języka polskiego używanego przez potomków polskich imigrantów W Brazylii. Podczas badań socjolingwistycznych w miejscowości Colônia Dom Pedro II w pobliżu Kurytyby zaobserwowano oznaki zaawansowanego procesu zanikania języka polskiego. Stwierdzono również, że jednym z głównych czynników odpowiedzialnych początkowo za zachowanie a następnie za przesunięcie językowe były niewątpliwie uwarunkowania społeczno-ekonomiczne panujące w tej miejscowości. Analiza biografii językowych i historii życia badanych wskazuje na znaczną zmianę cywilizacyjną we wsi oraz jej najbliższej okolicy, która rozpoczęła się na początku lat 70 . XX wieku, prowadząc do stopniowego zanikania ,języka ojców”. W tekście przedstawione są również fragmenty wypowiedzi respondentów i ich opinie na temat sytuacji językowej w kolonii, a w szczególności na zaobserwowane przez nich czynniki zachowania oraz przesunięcia językowego. SŁOWA KLUCZOWE: Język polski w Brazylii; Języki imigracyjne; Zachowanie i przesunięcie językowe.

\section{INTRODUÇÃO}

Brasil, considerado um dos países com maior diversidade linguística no mundo, é visto por uma grande parte de seus cidadãos, que sentem no seu dia a dia a nítida hegemonia da língua portuguesa, como um país monolíngue. No entanto, segundo os dados do IPOL (CARDOSO, 2016), no nosso país, além de duas línguas oficiais - o português e a língua brasileira de sinais - falam-se cerca de 250 línguas, das quais 56 são idiomas de imigrantes. O objeto do presente trabalho é uma dessas línguas, o polonês, presente nas práticas linguísticas de polono-descendentes, cujos ancestrais se estabeleceram em massa a partir do ano 1869 nas terras férteis, porém até então não cultivadas, dos estados meridionais do Brasil. Este texto objetiva identificar e analisar, por um lado, os fatores que permitiram a preservação da língua polonesa entre os imigrantes e seus descendentes, moradores de uma comunidade rural, por mais de um século e, por outro lado, os fatores que tenham causado um gradual abandono da língua dos ancestrais que tem sido observado nos últimos anos em várias pesquisas sobre as comunidades polonesas (MACIEL, 2010; PEREIRA, 2017; WEPIK, 2017; GOCZYŁA FERREIRA, 2019). 
O presente artigo deriva da pesquisa de Dissertação de Mestrado (GOCZYŁA FERREIRA, 2019), a qual investigou a presença da língua polonesa na Colônia Dom Pedro II (PR). O arcabouço teórico aplicado nesta análise inclui as áreas de Sociolinguística e de Manutenção e Substituição Linguística. A principal ferramenta metodológica utilizada foram as entrevistas semiestruturadas realizadas em polonês ou em português, dependendo da escolha do informante, com 48 dos cerca de 690 moradores da Colônia, dos quais aproximadamente 480 (70\%) são de ascendência polonesa. As variáveis implementadas na constituição da amostra foram o sexo e a idade dos informantes, divididos em três faixas etárias, a saber: 18-35 anos, 36-55 anos e acima de 55 anos. Os principais temas abordados durante as entrevistas foram: a história da família dos informantes e da Colônia; a presença da língua polonesa na localidade hoje e antigamente; as biografias linguísticas e a autoavaliação dos entrevistados acerca do conhecimento da língua polonesa falada na Colônia; o atual uso da língua na comunidade e a sua transmissão; a percepção de sua própria identidade; a manutenção das tradições e dos costumes trazidos da Polônia, entre outros.

Para responder as perguntas propostas neste artigo, a saber: "Por que a língua polonesa foi preservada na Colônia por cerca de cem anos?" e "Por que observa-se um declínio acentuado na presença da língua polonesa nas práticas linguísticas dos moradores?", focaremos principalmente as questões referentes à perspectiva histórica da presença da língua polonesa na Colônia e as vidas dos entrevistados, e suas opiniões quanto aos motivos da manutenção ou substituição da língua polonesa na comunidade. É premente destacar que, ao usar o termo "língua polonesa" no contexto desta pesquisa, referimo-nos à variedade dialetal do idioma polonês presente na localidade, cujas características serão mais tarde abordadas brevemente neste texto.

Embora a presente pesquisa trate da situação linguística somente em uma das muitas colônias polonesas no Brasil, acredita-se que seus resultados possam explicar uma parte significativa de fatores de manutenção/substituição linguística atuantes em outras localidades com perfis semelhantes.

A fim de se cumprir o que nos propomos, será apresentada brevemente, na próxima seção, a história da imigração polonesa no Brasil e da Colônia D. Pedro II, seguida pela parte teórica referente à Manutenção e Substituição Linguística. Na sequência passaremos a uma exposição dos dados numéricos referentes ao atual domínio de língua polonesa entre os informantes da pesquisa e às taxas de transmissão observadas na comunidade. Mencionaremos também as principais características da língua falada na Colônia. As seções seguintes se baseiam na análise qualitativa das entrevistas realizadas com os 
moradores da Colônia e são permeadas pelas citações de seus relatos. A primeira delas abordará os fatores de manutenção e de substituição linguística dentro do contexto da Colônia pesquisada, em perspectiva histórica, com divisão em quatro períodos. A segunda trará as respostas dos informantes à pergunta pelo motivo da drástica diminuição das taxas de transmissão da língua polonesa observadas na localidade.

\section{HISTÓRIA DA IMIGRAÇÃO POLONESA E A COMUNIDADE PESQUISA- DA}

A comunidade pesquisada foi uma das primeiras colônias polonesas estabelecidas em torno de Curitiba, as quais formavam um "cinturão verde" idealizado pelo presidente da Província do Paraná na época, Adolpho Lamenha Lins (WACHOWICZ, 1976). A partir do ano 1876, a Colônia Dom Pedro II se tornou um novo lar para famílias polonesas de origem camponesa, expulsas das suas terras natais pela pobreza extrema e pela falta de terra, condições causadas pela justaposição do processo de grande crescimento populacional e de uma estrutura agrária deficiente da região (MAZUREK, 2019). Ao mesmo tempo, os poloneses eram atraídos pela ativa e liberal política imigratória do governo brasileiro, para o qual o imigrante europeu era "pensado principalmente como um agente de defesa do território nacional e instrumento de colonização agrícola, cujo destino final seria a assimilação e cuja presença se justificava inclusive sob o mal disfarçado pretexto de "embranquecer a raça brasileira"” (OLIVEIRA, 2009, p. 3, grifo do autor).

Segundo as estimativas de Kula (1981), até a Eclosão da Primeira Guerra Mundial, cerca de 115 mil poloneses se estabeleceram no Brasil, dos quais 40 mil se instalaram no Paraná - estado com o maior número de imigrantes poloneses (MARTINS, 1941), onde esse grupo constituiu quase metade de todos os grupos imigrantes recebidos. Mais de 41 mil poloneses chegaram ao Brasil no período entre guerras (MAZUREK, 2019) ${ }^{1}$.

De volta à Colônia Dom Pedro II, seus fundadores, como 95\% dos imigrantes das terras polonesas na época, eram camponeses (WACHOWICZ, 1981), muitas vezes analfabetos, em busca de um pedaço de terra que garantisse seu futuro e de seus filhos. Como muitos de seus conterrâneos no Brasil, ao almejar a realização de seus sonhos, submetiam-se às duras condições de sobrevivência que encontraram na sua "terra

\footnotetext{
${ }^{1}$ Os números citados são aproximados. O estado polonês, existente desde o ano 966, estava sob ocupação de Prússia, Rússia e Império Austro-Húngaro e não existia no mapa mundi nos anos 1795-1918. Por isso, muitos imigrantes poloneses, ao chegar no Brasil, não possuíam um documento de identidade que confirmasse a sua etnia polonesa.
} 
prometida", em uma comunidade isolada geográfica- e socialmente de outros grupos populacionais da região. Como relata um dos atuais moradores da comunidade, os fundadores da Colônia

receberam do governo uma foice, um machado, uma enxada. Só. Tinham as terras demarcadas, só que eles ganharam o título e depois tiveram que pagar. Só que chegaram, aqui era tudo mato. (...) De lá saíram de extrema pobreza e aqui vieram na pior pobreza, os primeiros anos foi difícil. (homem, acima de 55 anos)

Quase 150 anos depois, a produção agrícola continua a base da economia da Colônia, embora as relações econômico-sociais tenham sofrido várias mudanças, o que será tratado nas seções seguintes do artigo. Os colonos não vivem mais em isolamento e mantêm contatos sociais e profissionais com moradores de outras localidades e com a capital paranaense, separada da Colônia por apenas 17 quilômetros, os quais antigamente eram praticamente intransponíveis. Durante quase um século e meio de sua existência, a comunidade e, com ela, as suas práticas linguísticas foram submetidas a grandes transformações influenciadas pelos fatores políticos, sociais, civilizatórios e culturais, entre outros. Para melhor compreensão dessas transformações apresentaremos em seguida os conceitos teóricos empregados ao longo do artigo referentes a manutenção/ substituição linguística.

\section{MANUTENÇÃO E SUBSTITUIÇÃO LINGUÍSTICA}

Os estudos de manutenção e substituição linguística (language maintenance and shift) ocupam-se, segundo o seu precursor Joshua Fishman (1964, p. 32): "por um lado, com a relação entre a mudança e a estabilidade no uso habitual de uma língua, e por outro lado, com os contínuos processos psicológicos, sociais e culturais que ocorrem quando populações de línguas diferentes estão em contato" "2. A manutenção de uma língua e a sua substituição são extremos de um contínuo, um leque de possíveis cenários desde a continuação de uso das línguas tradicionalmente usadas na comunidade (a manutenção) (FASOLD, 1984) até a situação na qual essas línguas não são mais usadas em uma comunidade e uma nova língua (ou línguas) aparece no seu lugar (a substituição).

\footnotetext{
${ }^{2}$ No original: "maintenance and language shift is concerned with the relationship between change or stability in habitual language use, on the one hand, and ongoing psychological, social or cultural processes, on the other hand, when populations differing in language are in contact with each other". Todas as traduções contidas neste artigo são de nossa autoria.
} 
Enquanto o contato entre as populações pode ocorrer em várias configurações político-sociais (cf. LIEBERSON et al., 1975; COUTO, 2009), a situação que concerne ao nosso objeto de pesquisa diz respeito a uma população migrante de menor poder político e/ou socioeconômico no território de um grupo majoritário, mantenedor desse poder (COUTO, 2009). Embora alguns teóricos considerem os grupos migrantes subordinados como fadados ao fracasso na preservação de sua língua (LIEBERSON et al., 1975), é de comum consenso entre a maioria dos pesquisadores da área de que "não existe um fator ou um conjunto de fatores que sempre preveem a manutenção ou a substituição linguística; ela depende de uma hierarquia específica entre os fatores em uma comunidade específica"3 (MEYER-SCOTTON, 2006, p. 105).

Apesar dessa imprevisibilidade dos resultados das configurações de fatores sociais, culturais, políticos e ideológicos dentro de uma comunidade, existem modelos e análises teóricas que permitem vislumbrar algumas tendências gerais observadas nos processos de manutenção/substituição linguística. Um dos modelos, baseado na organização espacial das comunidades e no padrão de multilinguismo na grande sociedade, é o de multilinguismo horizontal e multilinguismo vertical, proposto por Mansour (1993). Na ótica da pesquisadora, nas sociedades consideradas multilíngues, o espaço geográfico pode estar dividido em pequenas unidades, isoladas entre si, as quais mantêm suas respectivas línguas. As pequenas comunidades podem ser monolíngues, pois, por vezes, somente uma língua está presente nas suas práticas linguísticas; no entanto, no nível macro, estão inseridas em um contexto de multilinguismo horizontal.

Embora o conceito tenha sido cunhado para refletir o multilinguismo na África, parece descrever, até certo ponto, a situação de várias comunidades rurais de imigrantes europeus e seus descendentes no Brasil na segunda metade do séc. XIX e no começo do séc. XX. Certamente, esse termo se aplica à Colônia D. Pedro II, a qual, durante primeiros 50 anos de sua existência, caracterizava-se por baixos níveis de bilinguismo entre seus moradores, dos quais somente os homens maninham contatos comerciais com a população de língua portuguesa e usavam-na durante as suas expedições em busca de compradores de seus produtos agrícolas. Até a introdução do ensino na língua portuguesa na escola da Colônia, nos anos 1930, a língua polonesa imperava em casa, na igreja e em contatos com os vizinhos, o que ilustra o relato de uma das informantes:

\footnotetext{
${ }^{3}$ No original: "no one factor or set of factors always predicts language maintenance or shift; it depends on the specific hierarchy among factors in a specific community".
} 
Avó e avô só falavam em polonês. A minha avó não sabia falar em brasileiro. Tanto que não ensinou a minha mãe porque não sabia. Minha mãe não sabia falar brasileiro. E ficava braba quando falavam. O pai aprendeu brasileiro, a mãe, não. Ele trabalhava numa mina de ouro, já teve contato com as pessoas ${ }^{4}$. (mulher, acima de 55 anos)

Uma variante oposta ao multilinguismo horizontal é o multilinguismo vertical, no qual "dois ou mais grupos etnolinguísticos compartilham o mesmo território e participam de atividades socioeconômicas em comum" (MANSOUR, 1993, p. 19) - situação observada hoje em dia com cada vez mais intensidade na comunidade Dom Pedro II.

Obviamente, o primeiro cenário, o de multilinguismo horizontal, oferece condições muito mais propícias à manutenção da língua da comunidade (MEYERSCOTTON, 2006). Contudo, a sua permanência é um "beco sem saída" (dead-end road) que acaba na introspecção cultural e marginalização da língua minoritária em questão (MANSOUR, 1993, p. 19). A abertura das comunidades para contatos sociais e econômicos com grupos externos a elas leva ao aumento de níveis de bilinguismo entre os moradores e, consequentemente, pode desencadear o processo de substituição linguística, a qual não ocorre nas comunidades monolíngues. Todavia, o bilinguismo não precisa ser visto como um inimigo de preservação da língua tradicionalmente usada pelos grupos minoritários ou minorizados. Ademais, é justamente uma configuração de bilinguismo e de diglossia ${ }^{5}$ considerada por Fishman (1967) como um cenário mais seguro e estável para a preservação de línguas minoritárias. Se nas práticas linguísticas de falantes existem domínios reservados exclusivamente para a língua não majoritária na grande sociedade, como, por exemplo, os domínios de esfera privada e informal, a probabilidade da manutenção dessa língua na comunidade, na sua funcionalidade específica para o contexto dado, é significativa.

Uma miríade de fatores, tais como o tamanho do grupo dos falantes, seu status social, o tipo de comunidade, a presença da língua minoritária no ensino formal, entre muitos outros, que podem influenciar os processos de manutenção/substituição

\footnotetext{
${ }^{4}$ Fala original: "Dziadek i babka - wszystko po polsku. Babka nie umiała gadać po brazylijsku. Tanto que moją mamę nie nauczyła, bo nie umiała. Minha mãe não sabia falar brasileiro. I zła została, jakby godoć po brazylijsku. Tata się nauczył po brazylijsku, a mama nie. On robił numa mina de ouro, já teve contato com as pessoas." As transcrições na língua polonesa não refletem fenômenos fonéticos observados na fala dos informantes.

${ }^{5}$ Diglossia é entendida aqui no seu sentido mais amplo e se refere à distribuição de duas ou mais línguas que têm funções diferentes dentro de uma sociedade.
} 
linguística, foram identificados pelos pesquisadores desse campo de pesquisa. Todavia, os pesquisadores são concordes em que a atuação e peso de cada um desses fatores é uma função do contexto social, político, cultural e ideológico no qual a comunidade dos falantes da língua está inserida. Por isso, a análise dos fatores a seguir será apresentada na forma de um percurso histórico da situação linguística da Colônia Dom Pedro II em quatro fases: 1) desde sua fundação (1876) até o ano 1938 2) início dos anos 40 até início dos anos 70 3) anos 70 e início dos anos 80; 4) metade dos anos 80 até hoje. Sugere-se essa divisão em períodos, com base em entrevistas realizadas com os informantes nas partes que se referiam à história da Colônia e à presença da língua polonesa na vida dos moradores e às biografias linguísticas suas e de seus familiares.

\section{A ATUAL PRESENÇA DA LÍNGUA POLONESA E SUA TRANSMISSÃo NA COLÔNIA DOM PEDRO II}

Antes de embarcarmos em uma viagem no tempo, na história linguística da Colônia Dom Pedro II, vale apresentar um retrato da manutenção da língua polonesa na comunidade, observada durante a pesquisa realizada ao longo do ano 2018. A autoavaliação de suas competências linguísticas na "língua polonesa daqui", levada a cabo pelos pesquisados durante as entrevistas, demonstrou que $56 \%$ deles falam e entendem a língua dos ancestrais bem ou muito bem (nível 3), 27\% entendem bem ou muito bem e falam pouco ou não falam (nível 2) e 17\% somente entendem pouco (nível 1) a língua polonesa usada na Colônia. É notável a diferença diametral dos níveis de competência entre as faixas etárias, pois, enquanto no grupo acima de 55 anos, 94\% falam e entendem bem ou muito bem, na faixa etária de 18 até 35 anos, apenas 13\% demonstram esse domínio de língua polonesa. Chama atenção o fato de que a competência no nível 1, a mais baixa, foi observada somente no grupo mais jovem (18-35 anos). A análise multivariável demonstrou que a idade é a única variável social estatisticamente significativa na distribuição dos níveis de competência na língua polonesa no grupo pesquisado, o que indica que a diminuição nítida do domínio da língua observada entre os jovens não é atenuada por outras variáveis socais, tais como sexo, nível de escolaridade ou atuação profissional fora ou dentro da comunidade 6 .

\footnotetext{
${ }^{6}$ As seguintes variáveis dependentes foram consideradas na nossa análise: sexo, faixa etária, escolaridade, atuação dentro/fora da Colônia, estado civil, com filhos/sem filhos, permanência fora da Colônia por mais de um ano, residência junto com os pais.
} 
Ressaltemos que a língua polonesa presente na Colônia e falada pelos seus moradores constitui, segundo a terminologia de Dubisz (2014), um dialeto polonico, definido como "uma mistura de elementos de língua polonesa (em seus diferentes variantes), da língua do país de residência e das línguas de outros grupos étnicos com os quais as comunidades polônicas entram em contatos diretos"’7 (p. 88, grifo do autor). Em termos gerais, a variedade local da Colônia se caracteriza pela presença de:

- arcaísmos — por se tratar de assim chamada "velha emigração";

- regionalismos - pela origem camponesa dos fundadores da Colônia;

- germanismos, pois os imigrantes vieram dos terrenos ocupados na época pelo Império Austro-Húngaro;

- fortes influências do português brasileiro resultantes de contato linguístico com essa língua durante período de 150 anos (GOCZYŁA FERREIRA, 2019).

Para completar a nossa fotografia da preservação da língua polonesa na Colônia é necessário se debruçar sobre a condição sine qua non para a manutenção de uma língua: a sua transmissão dos pais para os filhos (FISHMAN, 2012). Segundo os resultados da pesquisa, mais da metade (53\%) dos informantes que são pais não transmitiu ou não transmite a língua polonesa para os seus filhos. Foram somente $28 \%$ dos pais entrevistados que ensinaram seus filhos a falar a sua língua étnica e 19\% que admitem terem feito isso de maneira parcial (os filhos demonstram algum nível de compreensão da língua). Essa imagem se mostra ainda menos otimista se apresentada com a divisão por faixa etária dos pais, o que apresenta o Gráfico 1.

\footnotetext{
${ }^{7}$ No original: “melanż elementów języka polskiego (w różnych jego wariantach), języka kraju osiedlenia oraz języków innych grup etnicznych, z którymi polonijne zbiorowości wchodzą w bezpośredni kontakt."
} 


\section{GRÁFICO 1 - AS TAXAS DE TRANSMISSÃO DA LÍNGUA POLONESA POR FAIXA ETÁRIA DOS PAIS NA COLÔNIA D. PEDRO II}

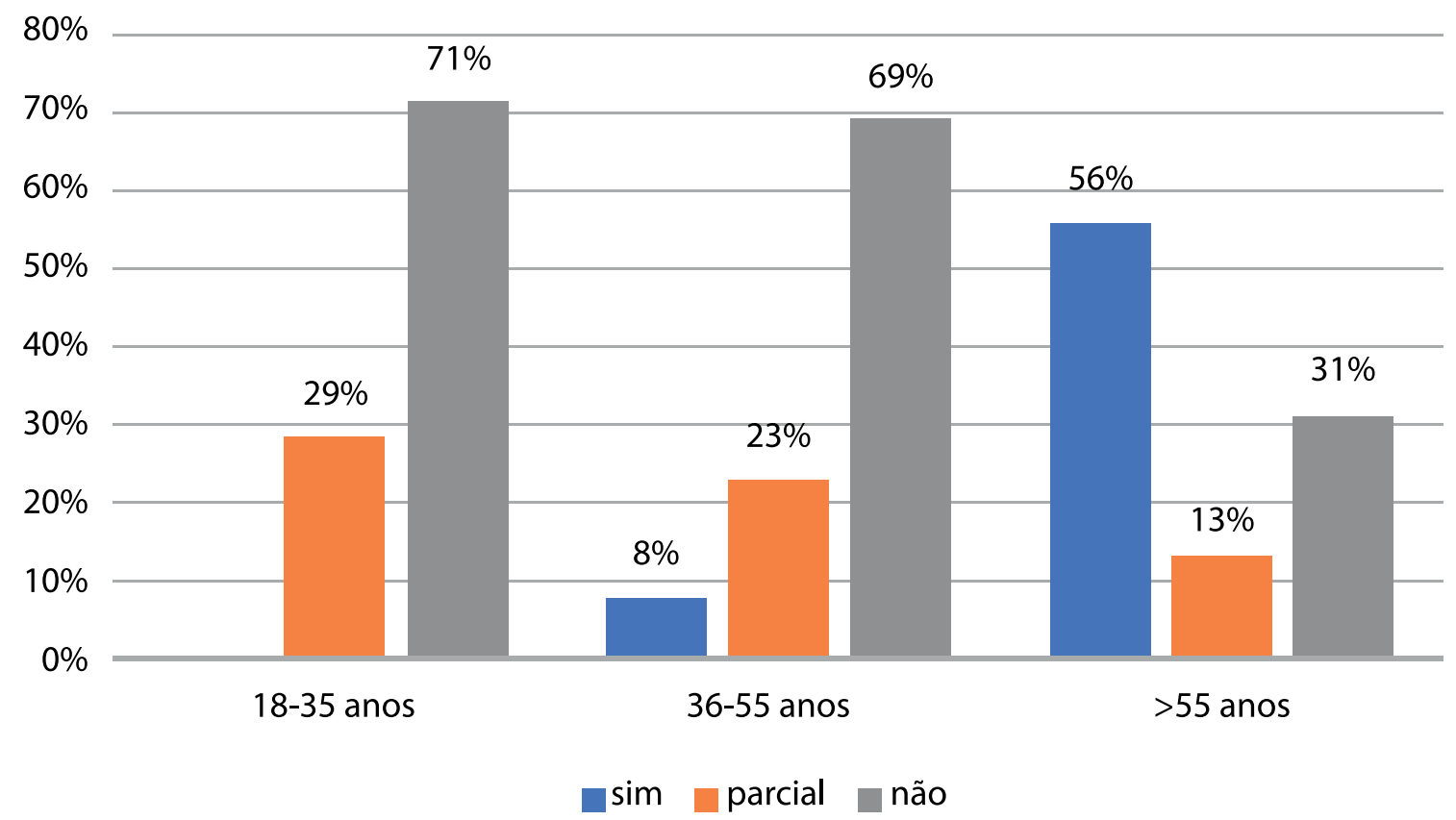

O Gráfico 1 não deixa dúvida de que a transmissão da língua polonesa dentro de casa não faz mais parte do cenário linguístico da Colônia. Para compreender o trajeto percorrido pela comunidade do final de século XIX, de multilinguismo horizontal, até a comunidade na qual a língua de imigração praticamente não é mais transmitida, faremos uma análise dos quatro períodos da história da Colônia, mencionados anteriormente.

\section{OS FATORES DE MANUTENÇÃO/SUBSTITUIÇÃO LINGUÍSTICA NA HISTÓRIA DA COLÔNIA DOM PEDRO II}

\section{Do ano 1876 até o ano 1938 - uma comunidade monolíngue (polonês)}

Como apontam várias pesquisas da área de manutenção e substituição linguística (cf. WEINREICH, 1974, THOMASON, 2001) comunidades rurais com baixa intensidade de contato com outros grupos, o que leva à baixa tendência à exogamia e resulta em grande homogeneidade étnica da localidade, tendem a preservar mais as suas línguas de origem. A importância da presença da língua minoritária nas práticas religiosas do grupo é mencionada, entre outros, pelos pesquisadores das línguas minoritárias no Brasil, tais como Dück (2005), Renk (2009) e Delong e Kersch (2018). Outro fator de manutenção 
linguística frequentemente apontado, por exemplo por Fishman (2012), é o ensino formal realizado na língua minoritária.

Todos os fatores supracitados existiam na Colônia D. Pedro II durante primeiros mais de 50 anos de sua existência, até o ano 1938, quando a língua portuguesa adentrou o domínio da escola, em resultado de políticas nacionalizadoras do Estado do Paraná e do Governo Federal. Até então, a comunidade, praticamente monolíngue de língua polonesa, era inserida no contexto de multilinguismo horizontal, definido na seção anterior. $\mathrm{O}$ ensino, até o ano 1908, era improvisado pelos colonos na casa de um deles. Nas palavras de um dos informantes:

Depois vieram as irmãs da Polônia, em 1908, que começaram a escola. Mas antes tinha um professor - Jakub Niemiec. Falavam que ele era uma pessoa letrada do Império da Áustria. Veio junto, trabalhava na roça e no domingo ensinava, até o ano 1908. Mas só os meninos iam para escola. Porque tinha que pagar. E só no domingo à tarde. Ensinava a ler, escrever e fazer conta. ${ }^{8}$ (homem, acima de 55 anos)

O ano 1908 foi marcado pela vinda à Colônia das Irmãs da Sagrada Família da Polônia, as quais fundaram uma escola primária, "reconhecida como escola de ensino oficial", onde o ensino ocorria na língua polonesa até o ano 1938.

Uma outra instituição mencionada frequentemente como uma grande contribuinte para a preservação da língua polonesa nas colônias no Brasil e fora dele é indubitavelmente a igreja católica. É mister mencionar que a identificação do catolicismo com a polonidade, observado pelos pesquisadores (SIUDA-AMBROZIAK, 2017; DELONG, 2018) e próprios pesquisados nas colônias polonesas até hoje, vem ainda das terras natais dos imigrantes poloneses, os quais muitas vezes podiam ter dúvidas quanto a sua nacionalidade, mas nunca quanto ao sua religião (KULA, 1981). Wachowicz chama as paróquias e os padres poloneses atuantes nas colônias de "único cimento que unia os colonos" (1981, p. 93, grifo do autor), tanto no sentindo espiritual, como na sua vida social. Aos primeiros moradores da Colônia D. Pedro II e seus descendentes no período analisado não faltava certamente a devoção pela igreja católica, pois, até o ano 1933, todo domingo percorriam os $22 \mathrm{~km}$ que os separavam da igreja polonesa mais próxima na Colônia Orleans: a pé, de carroça, depois, de caminhão.

\footnotetext{
${ }^{8}$ Fala original: “A później to siostry przyjechały z Polski w 1908, co zacynały szkołe. Ale przedtem był profesor - Jakub Niemiec. Mówili, że on był... era uma pessoa letrada do Império da Áustria. Przyjechał razem, robił na polu i w niedzielę uczył do 1908. Ale tylko chłopaki chodzili do szkoły. Bo trza było płacić i tylko w niedzielę po południu. Uczył czytać, pisać i robić rachunki."
} 
É notável que o catolicismo dos imigrantes poloneses no Brasil influenciou seu processo de assimilação de maneiras contraditórias. De um lado, considera-se que os povos imigrantes da mesma fé que a dominante no território de acolhimento se integram mais rapidamente na nova sociedade, o que pode levar à substituição linguística mais acelerada (WEINREICH 1974; THOMASON, 2001). Os casos opostos dessa situação no Brasil são, por exemplo, os de imigrantes alemães menonitas (DÜCK, 2005) ou ucranianos ortodoxos (RENK, 2009), nos quais a necessidade da leitura dos textos religiosos e da participação dos rituais na língua de imigração tiveram um grande impacto na preservação dessas línguas. A fé católica dos poloneses constituiria, teoricamente, uma ponte que facilitaria a sua entrada na sociedade brasileira meridional, caracterizada pela forte presença do catolicismo. Além disso, a estrutura hierárquica da igreja católica do Brasil obrigava os padres poloneses a atenderem também a população brasileira, alemã ou italiana e, consequentemente, a aprender a língua portuguesa (WACHOWICZ, 1981).

No entanto, o apego dos poloneses aos ritos especificamente poloneses dentro da igreja católica e a, já mencionada, indissociabilidade do sentimento de polonidade e da fé católica na mentalidade dos camponeses poloneses fizeram com que a igreja se tornasse um refúgio do mundo externo e, ao mesmo tempo, um ator importante na preservação da língua polonesa entre seus devotos. Até hoje, na Colônia D. Pedro II, a presença na missa dominical é um marcador da identidade dos moradores da localidade, o que comprovam as palavras de um dos nossos informantes:

A igreja é o centro. Se você não vai à igreja no domingo, você não faz parte da colônia. (homem, 18-35 anos)

De volta à situação linguística da Colônia até o ano 1938, dos relatos dos informantes, depreende-se que, nesse período, a comunidade constituía uma ilha linguística, certamente uma de várias “comunidades linguísticas e de assentamento (...) pequenas e fechadas, que surgem em um determinado ponto do território (...) de uma outra língua" (COUTO, 2009, p. 165), habitadas por colonos de ascendência europeia na época na região. Várias colônias polonesas e, entre elas, a Dom Pedro II devem ter correspondido à seguinte imagem descrita por um jornalista polonês da época:

Na colônia há uma igreja polonesa, lojas polonesas, os funcionários públicos poloneses ou brasileiros que falam um pouco polonês. Por isso, nas colônias falam português só aqueles que trabalham fora das colônias ou ocupam-se com comércio. Mulheres e crianças normalmente não entendem nenhuma palavra em português (HEMPEL, 1910 apud KULA, 1981, p. 102). 
A fase monolíngue da Colônia Dom Pedro II, com apenas alguns indivíduos bilíngues, encerra-se com o Decreto Federal no. 406 de 04 de maio de 1938, conhecido como "Lei da Nacionalização". Embora o processo de gradual exclusão de línguas estrangeiras da educação no Paraná já estivesse em curso, principalmente a partir dos anos 1920, foi a legislação federal do ano 1938 e a política de nacionalização de Getúlio Vargas que extinguiu as escolas étnicas no país (RENK, 2009).

As dependências da escola das Irmãs da Sagrada Família na Colônia D. Pedro II não fecharam as portas, como ocorreu com a grande maioria das 349 escolas polonesas existentes na época no Brasil. A comunidade teve sorte de não fazer parte das colônias que por vários anos, às vezes até 20, após o fechamento das suas escolas étnicas, não tiveram acesso a educação (WACHOWICZ, 1981). Contudo, não se tratava mais de uma escola polonesa, pois, para garantir o seu funcionamento, todas as matérias tinham que ser ministradas na língua portuguesa. Consideramos esse momento um marco na vida da Colônia e um início de um novo período na sua história linguística.

\section{Do ano 1938 até o início dos anos 1970 - diglossia}

Os informantes de mais idade que participaram da nossa pesquisa nasceram no final dos anos 1930, o que significa que não tiveram mais acesso ao ensino formal na língua polonesa. Viviam suas infâncias, adolescências e vidas de jovens adultos no período de uma diglossia na comunidade, com a língua portuguesa adentrando aos poucos o domínio da escola, deixando, por enquanto, intactos os domínios da casa, da igreja ou da vida comunitária. Foram eles a primeira geração de pessoas bilíngues - todos bilíngues sequenciais - com a língua polonesa como primeira língua e a língua portuguesa aprendida no ambiente escolar. Lembremos que a diglossia com bilinguismo é considerada por Fishman (1967) uma situação possivelmente estável e propícia a manutenção da língua étnica. No entanto, a exclusão da língua polonesa do ensino formal foi, sem dúvida, um dos fatores preponderantes no desencadeamento do processo de substituição linguística.

Vale ressaltar que essa exclusão do idioma polonês, por motivos práticos, não ocorreu da noite para o dia, pois:

Quando proibiram ensinar em polonês, as irmãs professoras também não sabiam falar brasileiro. ${ }^{9}$ (homem, acima de 55 anos)

\footnotetext{
${ }^{9}$ Fala original: "Jak zakazali uczyć po polsku, to siostry nauczycielki też nie umiały po brazylijsku."
} 
Ainda nos anos 1970, as irmãs-professoras praticavam o que hoje chamaríamos de translanguaging no seu sentindo original (GARCÍA, 2009), trocando de "modos linguísticos" entre as atividades receptivas e produtivas, como o percebemos na fala a seguir, que descreve a experiência da informante justamente dessa época:

Quando fui para escola, não sabia [falar] em brasileiro. (...) As irmãs falavam polonês e ensinavam em brasileiro. Só tinha crianças polonesas. ${ }^{10}$ (mulher, 36-55 anos)

$\mathrm{O}$ “ensinar em brasileiro" refere-se às atividades de leitura, sempre acompanhadas pelas explicações na língua polonesa. Essa função de língua auxiliar da língua polonesa no ensino na Colônia era presente ainda no começo dos anos 1980, o que comprova o seguinte relato:

Quando ela [professora] falava brasileiro e a gente não entendia, daí ela falava em polonês. ${ }^{11}$ (mulher, $36-55$ anos)

Assim, a manutenção da língua polonesa na escola pelas irmãs, de modo extraoficial, constituía uma tática de resistência frente ao sistema autoritário que impunha a homogeneidade linguística (cf. RIBEIRO, LEMKE, PUH, 2019). Desse modo, as irmãs tornaram menos traumáticos os primeiros encontros dos seus alunos com a língua portuguesa, mas também contribuíram possivelmente para a manutenção da língua dos ancestrais na comunidade, pois criaram, dentro de um domínio formal da escola, um domínio informal, ocupado por algum tempo pela língua polonesa.

Contudo, o papel da igreja na preservação da língua polonesa na Colônia não se limitava à atuação das professoras na escola. $80 \%$ dos informantes da faixa etária mais velha que admitem saber ler em polonês, no nível básico, atribuem essa habilidade aos contatos com as leituras realizadas na igreja, como contou uma das informantes, a qual admite não saber até hoje se confessar em português:

Ler? Sim, sei, em polonês. Aprendi assim na igreja, Lamentações, aprendi muito de lá, as ladainhas para a Nossa Senhora, para o Coração

${ }^{10}$ Fala original: "Ja poszła do szkoły, to ja nie umiała po brazylijsku. (...) [Siostry] gadały po polsku, uczyły po brazylijsku. Ino same polskie dzieci.”

${ }^{11}$ Fala original: "Pomagała, jak ona gadała po brazylijsku, jak człowiek nie rozumiał, to ona powiedziała potem po polsku." 
e Jesus. ${ }^{12}$ (mulher, acima de 55 anos)

Certamente, as crianças da Colônia tiveram contatos com a igreja católica, um reduto da língua polonesa, antes de iniciarem os seus estudos na escola, o que ilustra a fala de uma das informantes:

Minha mãe não sabia falar brasileiro. Mas eu aprendi. Tenho cinco anos da escola só. Eu aprendi, tipo na igreja, rezar em polonês, se confessar em polonês, tudo em polonês. Depois que fui mudando mais para o brasileiro. ${ }^{13}$ (mulher, acima de 55 anos)

Das falas supracitadas depreende-se a existência na Colônia de letramento litúrgico, o qual, por intermédio de eventos litúrgicos tais como rezas, terços ou missas, unia os falantes da língua polonesa e ajudava na sua preservação (DELONG; KERSCH, 2014).

Não obstante os esforços das irmãs-professoras em atenuar as possíveis dificuldades enfrentadas pelos seus alunos ao entrarem no sistema de ensino, onde se falava uma língua, para a maioria deles, estrangeira, os relatos dos ex-alunos referentes a esse processo são repletos de sensações de fracasso. É notável que as pessoas nascidas até o início dos anos 1950 admitem não ter aprendido muito bem a língua portuguesa por ter pouco contato com ela durante somente quatro anos de ensino, na maioria dos casos. Apesar de relatarem problemas na aprendizagem, reiteram a importância da ajuda obtida das professoras que se utilizavam da língua polonesa no processo de ensino. A maioria deles até hoje acredita dominar a língua polonesa melhor do que o idioma português. Nas palavras de uma delas:

é mais fácil [falar] em polonês. Eu fui ensinado em polonês. Em brasileiro sai, assim, atrapalhado. ${ }^{14}$ (homem, acima de 55 anos)

Essa descrição da fala "atrapalhada" acompanha várias narrativas das experiências

\footnotetext{
${ }^{12}$ Fala original "Czytać? Tak, ja umie tak po polsku. Takem się naucyła w kościele, Gorzkie Żale, ja się duzo naucyła stamtąd. Litanije to Matki Boskiej, do Serca Jezusowego.”

${ }^{13}$ Fala original: "Minha mãe não sabia falar brasileiro. Mas ja się naucyła. (...)". O resto da fala proferido na língua portuguesa.

${ }^{14}$ Fala original: “Łatwiej po polsku. Ja był nauczony po polsku, po brazylijsku takie atrapalhado wyjdzie."
} 
de se tornar bilíngue dos informantes nascidos a partir da metade dos anos 1950. Para muitos, o conhecimento anterior de língua polonesa foi um empecilho na aprendizagem do português, experiência da qual se deve proteger as próximas gerações, na opinião deles, o que ilustram as seguintes falas:

Foi difícil. Aprendemos a ler [em português] e logo, por causa disso, a língua enrolou. (homem, acima de 55 anos)

A mãe sempre dizia: 'não estude polonês, porque você vai ficar mal. Vai falar com a língua enrolada'. (mulher, 36-55 anos)

Percebamos que as transferências entre as línguas dominadas por uma pessoa bilíngue que resultam em uma "unidade linguística - diferente, mas completa", em virtude da "coexistência e da interação constante de duas línguas" (GROSJEAN, 1989, p. 6), é vista pelos informantes e, provavelmente, pelas pessoas do seu entorno como "a língua enrolada", como um obstáculo para uma comunicação eficiente. Essa crença negativa em torno da fala de indivíduos bilíngues é resumida por um dos nossos informantes da seguinte maneira:

Porque antigamente não era bonito falar duas, três línguas, não era legal. (homem, 18-35 anos)

É premente destacar que, hoje em dia, apesar de uma mudança na percepção de bi- e multilinguismo pelas sociedades em geral, o bilinguismo que abre um caminho para ascensão social inclui variedades "socialmente, regionalmente e geograficamente mais neutras possíveis" e não envolve variedades dialetais de línguas de imigração (HELLER, 2004, p. 83).

Resumindo, o período em tela, do ano 1938 até o início dos anos 1970, caracterizava-se pela presença de fatores que propiciavam a substituição linguística: a exclusão gradual da língua polonesa do ensino formal e os "fracassos" escolares no processo de aprendizagem no novo contexto; e de fatores que asseguravam a manutenção da língua polonesa: o papel da igreja com os eventos de letramento litúrgico e com a atuação das irmãs dentro da escola, como também a continuação das tendências isoladoras na comunidade, tais como endogamia, grande homogeneidade étnica e pouca intensidade de contatos com os grupos externos. Foi um período de diglossia com crescentes níveis de bilinguismo, o que favorecia a manutenção da língua dos ancestrais nos domínios por ela ocupados: casa, igreja e comunidade. 


\section{Início dos anos 1970 até início dos anos 1980 - a transformação}

Decidimos analisar esse curto período por separado, pois, conforme os relatos dos entrevistados, foi uma época de grandes transformações na vida da comunidade e, por conseguinte, na sua situação linguística. Um dos fatores que até então impedia a entrada da língua dominante em um número maior de domínios e preservava a posição da língua polonesa na comunidade foi o baixo nível de urbanização e de industrialização da região próxima à comunidade. Todavia, no ano 1969, foi inaugurada a BR-277, distante a $5 \mathrm{~km}$ do atual núcleo da Colônia, permitindo o acesso facilitado à capital paranaense, principalmente para donos de veículos.

Com a estrada, surgiu também a industrialização da região, a qual influenciou a vida da Colônia pelo menos de duas maneiras. Por um lado, as fábricas criadas na beira da BR ofereciam oportunidades de empregos para camponeses que, na época da crescente mecanização de agricultura, estavam à procura de possibilidades de aumentar a sua renda. Por outro lado, os mesmos empregos atraiam novos moradores, não polonodescendentes, para a região, os quais fundavam pequenas comunidades ao redor da estrada. As crianças das famílias recém-chegadas à região começaram a frequentar a escola das Irmãs da Sagrada Família na Colônia D. Pedro II, o que teve uma influência inestimável na mudança das relações sociais dentro da escola e, consequentemente, na Colônia.

Percebemos, portanto, o ingresso da língua portuguesa no domínio de trabalho de alguns moradores da comunidade e a sua presença ainda mais categórica no domínio de escola, onde as crianças de origem polonesa se tornaram minoria, obrigada a enfrentar a diminuição drástica da presença da língua polonesa nas práticas pedagógicas das professoras e a criar novos laços sociais com grupos que lhes eram estranhos até então. Um terceiro ponto de entrada do idioma português na localidade foi no domínio de entretenimento e informação, por intermédio de rádio e de televisão, acessíveis para a comunidade desde a metade dos anos 1970, quando ocorreu a conexão à rede elétrica.

Das entrevistas realizadas com os moradores da Colônia D. Pedro II pode se depreender que os contatos com os grupos étnicos diferentes do polono-descendente, que ocorriam na escola nos anos 1970, foram uns dos principais motivos que levaram os moradores da Colônia a perceberem, de uma maneira clara, a existência dos preconceitos étnicos contra os descendentes poloneses, mas também os seus próprios preconceitos para com outras etnias. Segundo Pereira (2017), o preconceito em relação aos polonodescendentes no Brasil, instituído historicamente, "parece acontecer de maneira ainda mais significativa do que o ocorrido contra os colonos vindos da Itália e da Alemanha, 
por exemplo" (p. 29), tese essa confirmada já anteriormente na pesquisa seminal de Ianni (1987).

Foram aventadas várias hipóteses quanto aos possíveis motivos desse preconceito. Para Wachowicz (1981), a monopolização da agricultura de subsistência no Paraná pelos imigrantes poloneses levou à identificação, nesse estado, do trabalho na lavoura, até então exercido pelas camadas consideradas mais baixas dentro da hierarquia social, com a etnia polonesa. Ianni (1987), por sua vez, acredita que, no momento das maiores ondas da chegada dos imigrantes poloneses, posterior à chegada dos grupos alemães e italianos na região, a sociedade paranaense já estava saturada de imigrantes. Os poloneses passariam, portanto, a exercer atividades já exercidas por outros grupos ou atividades não essenciais, causando descontentamento de outros imigrantes e da sociedade em geral. Seja como for, a existência de dois termos no português brasileiro para descrever as pessoas pertencentes à etnia polonesa, polonês e polaco, com as cargas semânticas bastante distintas, em constante mudança (cf. GOCZYŁA FERREIRA, 2019), comprova a presença histórica desse preconceito.

Aos entrevistados, o preconceito chegou na forma de xingamentos proferidos pelos seus novos amiguinhos na escola: "polaco batateiro", "polaco azedo", "polaco burro". Perguntados pelos motivos aparentes dos deboches, os informantes mencionavam o seu "sotaque" ao falar português ( $65 \%$ das menções) e os fatores relacionados com a sua condição socioeconômica: roupas mais simples, trabalho na roça e pouco estudo. $\mathrm{O}$ "sotaque" refere-se, nas falas dos entrevistados, praticamente exclusivamente ao, assim chamado por eles, "r puxado" - a pronúncia do tepe no lugar da fricativa posterior ou da vibrante múltipla /r/ nas palavras como "rato" ou "carro". Deparamo-nos, portanto, com um exemplo de preconceito linguístico, entendido como "uma atitude negativa frente a determinado grupo linguístico sem razão aparente” (BOTASSINI, 2013, p. 62), no qual os grupos de maior prestígio social avaliam de modo preconceituoso os falares diferentes do seu próprio. O mencionado "r puxado" tornou-se um estigma linguístico, um shibboleth, e, consequentemente, um motivo de vergonha e de insegurança linguística dos próprios polono-descendentes que levou muitos deles ao sentimento de deslealdade com o seu próprio falar. Nas palavras de duas de nossas informantes, uma acima de 55 anos (F3) e outra entre 18-35 anos (F1):

F3: Foi-se abandonando a fala polonesa para acompanhar o ritmo da cidade, ritmo das outras pessoas, das outras... culturas. Foram já acompanhando eles. E a nossa... ficou para trás. Por isso que a gente não ensinou mais os neto a falar. (...) Não sei se era, talvez um pouco 
de vergonha, né, porque chamavam de polaco burro, tipo assim, nois falava feio, não falava que nem o brasileiro falava bonito.

F1: Tinha essa vergonha, até bem há pouco tempo que começou essa parte da cultura, que foi resgatado. Alguns anos atrás não era, agora os filhos dançam...

Entrevistador: E por que da vergonha?

F1: Por causa dessas pessoas da vila. Falavam "polaco burro", "polaco azedo".

F3: As crianças traumatizam...

Chama atenção o fato de que o preconceito linguístico sofrido, juntamente com problemas já existentes na aprendizagem descritos na seção anterior, desencadeou a tomada de decisão de não transmitir a língua polonesa para os filhos ou para os netos. Não foram raras nas entrevistas as descrições de abandono da língua polonesa no domínio da casa, justamente em virtude da chegada dos filhos. Os pais sentiram-se responsáveis por proteger os seus filhos das dificuldades que eles mesmos enfrentaram na sua vida escolar, o que, para eles, significava protegê-los da grande culpada, a que deixava seus rastros, inaceitáveis, no jeito de falar dos pais - a língua polonesa. No entanto, do excerto supracitado, entendemos também que, em um momento posterior, houve um resgate da cultura polonesa e com ele a diminuição do sentimento da vergonha de ser polonodescendente, o que marcou o próximo período a ser analisado.

Antes de prosseguir, vale resumir os fatores atuantes na Colônia na década dos anos 1970. A crescente urbanização e industrialização da região da Colônia; o aumento dos contatos com outros grupos étnicos; a consciência do baixo prestígio linguístico da língua polonesa são os principais fatores responsáveis pelo "vazamento" da diglossia existente até então na comunidade e pela entrada da língua portuguesa no domínio da casa, domínio crucial na transmissão da língua minoritária (FISHMAN, 2012).

\section{Do início dos anos 1980 até hoje}

O final dos anos 1970 trouxe um acontecimento que impactou sobremaneira os poloneses e seus descendentes no mundo tudo. A escolha de um padre polonês para o cargo de Papa "estimulou a preservação de costumes e tradições polonesas incorporadas à religiosidade polônica e possibilitou o resgate do patrimônio cultural dos polonobrasileiros" (SIUDA-AMBROZIAK, 2017, p. 18). Os nossos entrevistados confirmaram o ressurgimento do orgulho de ser polono-descendente, de língua e de cultura polonesa na Colônia em virtude desse evento, o qual, na perspectiva deles, aumentava o seu prestígio 
social dentro da sociedade brasileira. Paradoxalmente, o início dos anos 1980 foi também um momento quando a língua polonesa perdeu seu último domínio exclusivo na Colônia - a igreja. Apesar da presença de um pároco polonês durante todo o período a partir do ano 1933, as missas começaram a ser celebradas em português, para que todos os fiéis, também os mais jovens e os não polono-descendentes, pudessem acompanhá-las. Hoje em dia, somente um dos elementos fixos da missa, "Cordeiro de Deus", é mantido em polonês e acompanhado de alguns poucos cantos nessa língua. Os entrevistados afirmam que mesmo as canções natalinas polonesas, cantadas praticamente por todos os informantes durante as nossas entrevistas, ressoam com cada vez menos frequência durante as celebrações natalinas na igreja da Colônia.

Vários informantes, principalmente do grupo etário abaixo de 36 anos, admitiram murmurar os cantos poloneses na igreja sem entender seu significado exato. Observamos, portanto, nas gerações mais novas, a substituição da função comunicativa da língua polonesa pela função ritualística. A seguinte fala de uma informante, participante do grupo musical na igreja, exemplifica bem o fenômeno descrito:

A gente canta bastante e eu não entendo o que eu canto. Eu canto, porque já sei, já decorei, mas não entendo o que está escrito ali. (mulher, 18-35 anos)

Naturalmente, da perspectiva de manutenção da língua, essa transformação precisa ser vista como um movimento na direção da substituição linguística (THOMASON, 2001). No entanto, como assevera Rappaport (1990), que percebeu esse fenômeno em uma comunidade de polono-descendentes nos Estados Unidos: "é interessante que a língua polonesa passa por um tipo de renascimento, mas em uma função nova: função de uma língua ritual, a qual não precisa ser compreendida, mas a qual serve como uma declaração de identidade étnica"15 (p. 175).

É curioso que o acesso às novas tecnologias parece reforçar a função ritualística e emblemática da língua polonesa na Colônia, em vez de promover o desenvolvimento do uso do idioma para a comunicação, como observado por Dębski (2016) nas comunidades polono-descendentes na Austrália. Os nossos informantes compartilham, por meio de aplicativos, vídeos e canções com conteúdos religiosos e folclóricos, os quais reproduzem o seu mundo polonês da Colônia, mundo apegado às tradições polonesas e ao catolicismo.

${ }^{15}$ No original: “(...) interesujące jest to, iż język polski przeżywa rodzaj wskrzeszenia, ale w nowej funkcji: funkcji języka rytualnego, który nie musi być zrozumiały, lecz który służy jako deklaracja etnicznej tożsamości." 
O acesso facilitado à internet, no caso dos jovens da Colônia D. Pedro II, tende a propiciar o processo de substituição linguística, como constatado por Tambor (2018). Segundo a pesquisadora, a internet e, com ela, os contatos com os amigos nas redes sociais assumiram o papel na educação linguística dos jovens até então cumprido principalmente pelos familiares que moravam na mesma casa.

Podemos concluir, portanto, que a grande presença da internet na vida dos jovens seria uma das culpadas pelo desaparecimento de um modo de vida que é uma condição sine qua non da transmissão da língua minoritária, chamado por Fishman (2012) de "casafamília-vizinhança-comunidade" (home-family-neighborhood-community life). Na ótica do pesquisador, a concentração geográfica e intergeracional da vida de uma comunidade permite que uma grande parte das interações informais e íntimas de crianças ocorra na "tradicional língua étnica materna" (FISHMAN, 2012, p. 473) e forneça as condições de espontaneidade e intimidade imprescindíveis para a transmissão da língua materna dos pais para os filhos.

Obviamente, a gradual mudança de estilo de vida na comunidade não ocorreu apenas com o advento das novas tecnologias. Um dos fatores relevantes foi a disponibilidade de ensino médio na Colônia a partir do ano 1989, o qual abriu, para os jovens polonobrasileiros, um leque de oportunidades de educação e de carreira fora das fronteiras da comunidade. Os níveis mais altos de formação levaram à melhor situação econômica a qual, por sua vez, permitiu que várias famílias jovens possuíssem suas casas próprias, já não intergeracionais (por exemplo, sem a presença dos avós), dentro da Colônia. A propósito, a importância do contato com os avós na preservação da língua de imigração, já constatado por outros pesquisadores da língua polonesa (NUNES, 2018) ou ucraniana (RIBEIRO; LEMKE; PUH, 2019) no Brasil, foi confirmada por vários dos nossos informantes, principalmente da faixa etária mais jovem, o que exemplifica a seguinte fala:

Até quando a vó tava viva, eu falava. Tudo errado, mas ela me entendia. Eu me obrigava um pouco, porque às vezes ela estava bem fraca $\mathrm{e}$ conseguia falar só em polonês. (...) Agora não lembro mais. (mulher, 18-35 anos)

Resumindo, esse último período foi marcado na Colônia pela continuação das transformações sociais resultantes da abertura cada vez maior da comunidade para o mundo exterior e maior acesso à educação e a oportunidades de emprego, nos quais o conhecimento da língua polonesa é dispensável. Essa passagem para a configuração de multilinguismo vertical trouxe mudanças no estilo de vida dos moradores da Colônia, os quais começaram a formar núcleos familiares menores, abertos aos contatos com os 
membros de outros grupos étnicos. A língua polonesa perdeu a sua exclusividade nas celebrações litúrgicas dentro da igreja, porém manteve e, em alguns casos, ganhou a função de língua ritual e emblemática, presente em festas folclóricas e de cultura polonesa organizadas na comunidade.

Destaca-se que a língua polonesa ainda está presente no dia a dia de algumas famílias e não perdeu totalmente a sua função comunicativa, principalmente nos núcleos familiares intergeracionais. No entanto, todos os informantes afirmaram terem percebido a drástica diminuição do uso da língua polonesa na Colônia, o que nos levou a perguntar pela sua opinião quanto ao motivo do abandono da língua étnica na comunidade. As suas respostas serão apresentadas na próxima seção.

\section{POR QUE SE FALA CADA VEZ MENOS POLONÊS NA COLÔNIA DOM PEDRO II?}

O percurso histórico da presença da língua polonesa na Colônia pesquisada, apresentado neste artigo, é baseado nos relatos dos informantes da pesquisa. No entanto, consideramos importante complementá-lo com a visão deles quanto ao atual desaparecimento gradual da língua dos ancestrais na localidade. O motivo mais frequentemente mencionado pelos pesquisados é a obsolescência e a inutilidade da língua polonesa, resumida na frase proferida por um dos informantes:

Polonês é bonito, mas aqui se fala português. ${ }^{16}$ (homem, 36-55 anos)

Em outras palavras, os pesquisados enxergam o valor social da língua polonesa no seu contexto como baixo e insuficiente para que os esforços necessários para a sua transmissão valham a pena.

O segundo motivo mais mencionado pelos pesquisados são as atitudes dos pais, o que em muitos casos significa assumir "culpa" pela falta da preservação da língua na família. Os entrevistados institivamente sentem o que os pesquisadores têm comprovado, ou seja, a importância das atitudes linguísticas, tais como lealdade linguística, no processo de manutenção/substituição linguística (HESBACHER; FISHMAN, 1965; WEINREICH, 1974). A lealdade linguística é entendida aqui como um estado mental no qual a língua assume uma alta posição na escala de valores de um grupo e que pode se manifestar, por exemplo, pelo esforço de usá-la em vários contextos, pela sua resistência às transferências

\footnotetext{
${ }^{16}$ Fala original: "Polski ładny, ale tu się po portugalsku gada."
} 
de outras línguas ou pela sua transmissão para as próximas gerações (WEINREICH, 1974). Os nossos informantes se arrependem por terem adotado comportamentos opostos aos de lealdade linguística, a saber, por terem feito poucas exigências na educação linguística dos filhos (fala 1) ou por não terem mantido o hábito de conversar na língua polonesa em casa (fala 2):

(1) Faltou um pouco o pai pegar, assim, mais firme. Não dá para controlar... ${ }^{17}$ (homem, acima de 55 anos)

(2) Se a gente falasse mais, esses jovens aprenderiam mais. ${ }^{18}$ (mulher, 36-55 anos)

Outros acreditam que a responsabilidade jaz nas atitudes linguísticas das gerações mais jovens, as quais sentem vergonha da sua origem e da língua dos ancestrais ou, na opinião de alguns, simplesmente não querem aprender o idioma.

Entre os motivos mais citados aparecem também os fatores socioeconômicos já discutidos, como a crescente tendência à exogamia que resulta em maior heterogeneidade étnica na Colônia. Os entrevistados notaram também a influência da atuação profissional fora da comunidade e, consequente, diminuição do tempo passado em casa com a família, o que Fishman (2012) chamaria de abandono do estilo de vida "casa-família-vizinhançacomunidade".

Chama atenção o fato de que nenhum dos entrevistados tenha citado a falta de apoio institucional na manutenção da língua de imigração como um dos fatores que tenha exercido influência na atual situação linguística da Colônia. Os pesquisados, talvez não cientes de que esse tipo de apoio seja possível, assumem responsabilidade pela preservação ou pela substituição da sua língua étnica na comunidade. A única instituição mencionada, ainda que raramente, é a igreja, a qual, segundo alguns, não precisava ter deixado de lado a língua polonesa de forma tão contundente e até hoje poderia ainda contribuir para a preservação da língua, como contou um dos informantes:

Se nós estivesse continuado..., começasse dois domingo em polonês, mesmo se fosse um domingo. Todos esses que participavam, aprendiam só ali. Mas uma grande maioria... o básico tinha aprendido, sem ter aprendido [estudado]. (homem, acima de 55 anos)

\footnotetext{
${ }^{17}$ Fala original: "Trochę brakowało ojcu tak wziąć, jakoś tak mais firme. [...] Nie da rady upilnować."

${ }^{18}$ Fala original: “Żeby my więcej gadały, to by te jovens się nauczyły bardziej.”
} 


\section{CONSIDERAÇÕES FINAIS}

Como foi apresentado ao longo do artigo, a Colônia D. Pedro II, durante os seus quase 150 anos de existência, percorreu um trajeto de uma comunidade monolíngue de fala polonesa, o qual perdurou aproximadamente 50 anos, até uma comunidade ainda bilíngue, porém com a drástica diminuição do domínio de língua polonesa e de sua transmissão nas gerações mais jovens. $\mathrm{O}$ fato de que, ainda hoje, mais da metade dos informantes consiga conversar com a entrevistadora na língua polonesa, às vezes durante horas, é notável. O período tão longo da preservação da língua de ancestrais deve-se aos fatores socioeconômicos, culturais e políticos analisados nas seções anteriores, mas também aos esforços dos polono-descendentes, que mantiveram vários elementos da cultura trazida pelos seus ancestrais, apesar de condições muitas vezes adversas, como a nacionalização do ensino ou o preconceito sofrido na escola e fora dela.

A língua polonesa, principalmente a variedade falada na Colônia, permanece para um terço dos pesquisados, na maioria pessoas da faixa etária mais velha, como sendo a depositária de sua identidade e de sua cultura. Por outro lado, o mesmo número de pesquisados a considera obsoleta e inútil - dado preocupante pois corresponde às opiniões dos mais jovens. No entanto, os acontecimentos recentes na Colônia mostram que uma grande parcela dos moradores da comunidade percebe na língua polonesa um valor merecedor de seu tempo e de seu investimento. Graças à iniciativa da comunidade e do apoio financeiro do Consulado da Polônia, desde março $2019^{19}$, são ofertadas na comunidade aulas de língua polonesa, as quais causaram grande interesse entre os moradores na faixa etária de 12 a 70 anos. Obviamente, não queremos afirmar que uma ação isolada possa se tornar uma panaceia para os problemas da preservação da língua polonesa na comunidade, nem que as aulas de língua polonesa, em boa parte - língua padrão, possam reverter a forte tendência de substituição linguística. Todavia, como os nossos pesquisados, esperamos que seja um bom começo para a revitalização da língua polonesa na comunidade e que essa ação seja seguida de outras ações de sensibilização à variação linguística e cultural e ao bilinguismo, realizadas não somente no ambiente extraescolar, mas também dentro da escola da Colônia.

Valendo-se da fala de um dos informantes: "Hoje mudou totalmente os costumes, misturou as gerações com os brasileiro" e nem deve ser diferente. Essas mudanças

\footnotetext{
${ }^{19}$ Devido a pandemia do COVID-19, as aulas não foram retomadas até o momento (julho, 2020) nesse ano.
} 
ocorreram também como uma tentativa de fuga da marginalização, em busca de uma ascensão social dentro da sociedade brasileira, à qual os polono-descendentes pertencem. Por isso, acreditamos que a preservação ou a revitalização da língua polonesa na Colônia só é viável por intermédio de políticas e de ações que contemplem ambas as línguas que compõem as identidades híbridas dos nossos informantes, ações que promovam o bilinguismo e a educação bilíngue, tão pouco conhecida, até hoje, pelos moradores da comunidade. 


\section{REFERÊNCIAS:}

BOTASSINI, Jacqueline O. M. Crenças e atitudes linguísticas: um estudo dos róticos em coda silábica no norte do Paraná. 2013. 220 f. Tese (Doutorado em Estudos da Linguagem) - Centro de Letras e Ciências Humanas, Universidade Estadual de Londrina, Londrina.

CARDOSO, Mônica. Plataforma do Letramento: O Brasil e suas muitas línguas, 2016. Disponível em: <http://ipol.org.br/tag/linguas-do-brasil/>. Acesso em 20 jun. 2020.

COUTO, Hildo H. do. Linguística, ecologia e ecolinguística: contato de línguas. São Paulo: Editora Contexto, 2009.

DĘBSKI, Robert. Dynamika utrzymania języka polskiego w Australii. Postscriptum Polonistyczne, 1 (17), p. 133-150, 2016.

DELONG, Silvia R.; KERSCH, Dorotea F. Perfil de descendentes de poloneses residentes no sul do Brasil: a constituição da(s) identidade(s).Domínios de Lingu@gem, v. 8, n. 3, p. 65-85, 2014.

DELONG, Silvia R.; KERSCH, Dorotea F. "O jeito polonês é um pouco diferente do brasileiro": Manifestações das identidades étnico-linguísticas dos descendentes de poloneses no Sul do Paraná. Antares: Letras e Humanidades, v. 10, n. 21, p. 37-54, 2018.

DUBISZ, Stanisław. Językoznawcze studia polonistyczne, t. 2, Polonia i jej język, Warszawa: Uniwersytet Warszawski, 2014.

DÜCK, Elvine S. Witmarsum, uma comunidade trilíngue: Plautdietsch, Hochdeutsch e português. 2005. 152 f. Dissertação (Mestrado em Estudos Linguísticos) - Setor de Ciências Humanas, Letras e Artes, Universidade Federal do Paraná, Curitiba.

FASOLD, Ralph. The Sociolinguistics of Society. Introduction to Sociolinguistics. v.1. Oxford/New York: Basil Blackwell, 1984.

FISHMAN, Joshua A. Language maintenance and language shift as a field of inquiry. A definition of the field and suggestions for its further development. Linguistics. v. 2, n. 9, p. 32-70, 1964.

FISHMAN, Joshua A. Bilingualism with and without diglossia; diglossia with and without bilingualism. Journal of Social Issues. Vol. XXIII, n. 2, p. 29-38, 1967. 
FISHMAN, Joshua A. Language Maintenance, Language Shift, and Reversing Language Shift. In: BHATIA, Tej K.; RICHIE William C. (Org.). The Handbook of Bilingualism and Multilingualism. Wiley-Blackwell, 2012. p. 466-494.

GARCÍA, Ofelia. Bilingual Education in the 21st Century: A Global Perspective. Wiley Publishing. Edição do Kindle, 2009.

GOCZYŁA FERREIRA, Alicja. A presença da língua polonesa na Colônia Dom Pedro II, Campo Largo, Paraná. 2019. 222 f. Dissertação (Mestrado em Letras) - Setor de Ciências Humanas, Universidade Federal do Paraná, Curitiba.

GROSJEAN, François. Neurolinguists, Beware! The Bilingual Is Not Two Monolinguals in One Person. Brain and Language, 36, p. 3-15, 1989.

HELLER, M. Globalization and the commodification of languages In: CABRÉ, M.T.; LORENTE, M; SOLÉ, E. (Orgs.). Linguística Aplicada. Cicle de conferències i seminaris 98-00. Barcelona: Universitat Pompeu Fabra, 2004. p. 77-88.

HESBACHER, Peter; FISHMAN, Joshua A. Language Loyalty: Its functions and concomitants in two bilingual communities. Lingua. 13, p. 145-165, 1965.

IANNI, Octavio. Raças e classes sociais no Brasil. São Paulo: Editora Brasiliense, 1987.

KULA, Marcin. Polonia brazylijska. Warszawa: Ludowa Spółdzielnia Wydawnicza, 1981.

LIEBERSON, Stanley; DALTO, Guy; JOHNSTON, Mary E. The Course of MotherTongue Diversity in Nations. American Journal of Sociology. v. 81, n. 1, p. 34-61, 1975.

MACIEL, Myrna E. M. Línguas de imigrantes: a língua polonesa na Região Sul do Brasil. 2010. 98 f. Dissertação (Mestrado em Ciências da Linguagem) - Universidade do Sul de Santa Catarina, Florianópolis.

MANSOUR, Gerda. Multilingualism and Nation Building. Clevedon, UK: Multilingual Matters, 1993.

MARTINS, Romário. Quantos somos e quem somos. Curitiba: Paranaense, 1941.

MAZUREK, Jerzy. O caráter específico da imigração polonesa para o Brasil. Polonicus Revista de reflexão Brasil - Polônia, Ano X - 1/2019, p. 34-57, 2019.

MYERS-SCOTTON, Carol. Multiple voices: an introduction to bilingualism. Oxford: Blackwell Publishing, 2006. 
NUNES, Rozele B. O bilinguísmo português/polonês na constituição disposicional e na prática: perfis sociológicos de cinco descendentes de poloneses no município de Dom Feliciano/RS. 2018. f. 255. Tese (Doutorado em Educação) - Faculdade de Educação, Universidade Federal de Pelotas, Pelotas.

OLIVEIRA, Márcio de. Os poloneses do Paraná (Brasil) e a questão da nacionalização dos imigrantes (1920-1945). In: SIMPÓSIO NACIONAL DE HISTÓRIA, 25., 2009, Fortaleza. Anais do XXV Simpósio Nacional de História - História e Ética. Fortaleza: ANPUH, 2009.

PEREIRA, Ivelã. A voz de polono-brasileiros: um contexto histórico sul paranaense. Working Papers em Linguística, 18(1), p. 23-45, 2017.

RAPPAPORT, Gilbert. Sytuacja językowa Amerykanów polskiego pochodzenia w Teksasie. In: MIODUNKA, Władysław (Org.), Język polski w świecie. Kraków: PWN, 1990.

RENK, Valquiria E. “Aprendi falar português na escola!” O processo de nacionalização das escolas étnicas polonesas e ucranianas no Paraná. 2009. 243 f. Tese (Doutorado em Educação) - Setor de Educação, Universidade Federal do Paraná, Curitiba.

RIBEIRO, Hermínia A.; LEMKE, Cibele K.; PUH, Milan. Entre Estratégias e Táticas: A Manutenção de Línguas de Imigração em Irati, Paraná. Línguas \& Letras, v. 20, n. 46, p. 7-26, 2019.

SIUDA-AMBROZIAK, Renata. Religião na construção da identidade étnica dos polonobrasileiros. In: AUGUSTO, I. R.; DADALTO, M. C.; SIUDA-AMBROZIAK, R. (Orgs). Subjetividade em trânsito: Memória, emoção, e-imigração e identidades. Rio de Janeiro: Editora Bonecker, 2017. p. 11-38.

TAMBOR, Jolanta. Po polsku, po brazylijsku i po portugalsku - o świadomości językowej Polonii brazylijskiej. Odrodzenie i zanikanie języka. Postscriptum Polonistyczne, 1 (21), p. 221-236, 2018.

THOMASON, Sarah G., Language Contact. Edinburgh: Edinburgh University Press, 2001.

WACHOWICZ, Ruy Ch. Órleans: um século de subsistência. Curitiba: Editora. Paiol, Fundação Cultural de Curitiba, 1976.

WACHOWICZ, Ruy Ch. O camponês polonês no Brasil. Curitiba: Fundação Cultural, 1981. 
WEINREICH, Uriel. Languages in Contact. Findings and Problems. London-The HagueParis: Mouton \& Co, 1974 [1953].

WEPIK, Fernanda F. Crenças e atitudes linguísticas de polono-brasileiros de Áurea/RS e Nova Erechim/SC: o uso dos termos de parentesco. 2017. 144 f. Dissertação (Mestrado em Estudos Linguísticos) - Universidade Federal da Fronteira Sul, Chapecó. 